\title{
Purification of a set of cellular polypeptides that bind to the purine-rich cis-regulatory element of herpes simplex virus immediate early genes
}

\author{
Karen L. LaMarco and Steven L. McKnight \\ Howard Hughes Medical Institute, Carnegie Institution of Washington, Baltimore, Maryland 21210 USA
}

\begin{abstract}
Expression of herpes simplex virus type 1 (HSV1) immediate early (IE) genes is activated by a polypeptide component of the mature virion termed viral protein 16 (VP16). Stimulation of IE expression by VP16 operates via two cis-regulatory sequences: TAATGARAT, and the purine-rich hexanucleotide sequence GCGGAA. VP16 does not bind directly to either of the IE cis-regulatory sequences. Rather, these elements appear to represent binding sites for host cell proteins. Herein, we report the purification of a host cell factor that binds to the GCGGAA motif. We show further that this factor is capable of binding in vitro to an oligomerized form of the hexanucleotide sequence GAAACG, which is common to a variety of virus- and interferon-inducible genes. The GAAACG repeats of interferon- and virus-inducible genes, and the GA-rich repeats of HSV1 IE genes confer similar functional properties when appended to the promoter of a heterologous gene. These observations raise the possibility that HSV1 may activate its IE genes in a manner that exploits one of the components used by mammalian cells to combat virus infection.
\end{abstract}

[Key Words: HSV1; DNA-binding proteins; IE gene expression; VP16]

Received June 19, 1989; revised version accepted July 12, 1989.

The life cycle of herpes simplex virus type 1 (HSVI) proceeds through three temporally regulated tiers, each characterized by the expression of a unique class of proteins; these include the immediate early (IE), delayed early, and late polypeptides (Honess and Roizman 1974). Activation of IE genes is achieved by a constituent of the mature virion, termed viral protein 16 (VPl6) (Post et al. 1981). This trans-activator protein is encoded by the HSVl genome, synthesized as a late polypeptide, and assembled into the tegument of the mature virion (Campbell et al. 1984). Mutational dissection of HSV1 IE genes has disclosed two conserved DNA sequence motifs that are required in cis for VP16-mediated activation of IE transcription; one motif bears the nonanucleotide sequence TAATGARAT $(\mathrm{R}=$ purine $)$; the other is a purine-rich hexanucleotide sequence GCGGAA (Mackem and Roizman 1982a,b; Cordingley et al. 1983; Kristie and Roizman 1984; Gaffney et al. 1985; Bzik and Preston 1986; O'Hare and Hayward 1987; Triezenberg et al. 1988a). Surprisingly, VP16 does not bind directly to either of these conserved motifs, nor does it possess general DNA-binding properties (Marsden et al. 1987; S. Triezenberg, unpubl.). Thus, VP16 appears to trans-activate IE gene expression by an alternate, less direct pathway.

In a recent report, we identified two chromatographically separable, sequence-specific DNA-binding activities that may play a role in facilitating HSVI IE gene expression (Triezenberg et al. 1988a). Both activities also are present in the nuclei of uninfected cells; one is capable of sequence-specific binding to the TAATGARAT motif, whereas the other recognizes the GA-rich element. In addition, we showed that clustered point mutations that inhibit VP16-dependent induction of IE transcription in vivo, also hamper protein binding to these sequences in vitro. Becuase VP16 is IE gene specific, yet is incapable of direct interaction with its cognate, IE-specific cis-regulatory elements, we suggested that VP16 achieves gene specificity via host cell DNA-binding activities (Triezenberg et al. 1988a,b|. If this is indeed the case, VP16 may interact with cellular factors in one of two ways: It could act indirectly by triggering intracellular signaling events that culminate in the activation of cellular proteins that bind to IE cis-regulatory elements. Alternatively, VP16 might function at the site of transcription initiation via protein-protein interaction with cellular proteins that bind to IE cis-regulatory sequences. Several lines of evidence have emerged in support of the latter model. For example, VP16 can form a ternary complex with the TAATGARAT element and a cellular DNAbinding activity (Kristie and Roizman 1987, 1988; McKnight et al. 1987; Gerster and Roeder 1988; O'Hare and Goding 1988; Preston et al. 1988). Moreover, VP16 has been shown to harbor an acidic transcriptional acti- 
vating domain close to its carboxyl terminus that is required for induction of IE gene transcription (Triezenberg et al. 1988b). When the acidic activating domain of VP16 is attached to the DNA-binding domain of GAL4, a regulatory protein from yeast, it acts as a potent transcriptional activator in vivo (Sadowski et al. 1988). Because prototypical acidic activating domains are tethered to their sites of action via intramolecular linkage to a sequence-specific DNA-binding domain (for review, see Ptashne 1988), we hypothesized that VP16, too, acts at the site of transcription. However, unlike conventional activator proteins, VP16 is hypothesized to become associated with IE genes via protein-protein interactions with cellular DNA-binding proteins (Triezenberg et al. 1988a,b).

Gel retardation assays have revealed that VP16 can associate with the TAATGARAT element in the presence of the transcription factor $\mathrm{OTF}_{1}$ (Gerster and Roeder 1988; O'Hare and Goding 1988). Similar assays have failed to provide evidence of complex formation between VP16, the GA-rich motif, and its cognate-binding activity (C. Vinson and K. LaMarco, unpubl.). If the GArich element and its binding activity do not provide an attachment site for VP16, why does this element play so crucial a role in facilitating VP16-mediated transcriptional activation? In hopes of learning more about how the GCGGAA motif operates in the context of HSVI IE transcription, we have undertaken the task of purifying a cellular DNA-binding activity that recognizes the GA motif in vitro. Provisionally, we term this activity immediate early facilitator (IEF), and distinguish it from the activity that binds to TAATGARAT by the lower case, subscript suffix, ga $\left(\mathrm{IEF}_{\mathrm{ga}}\right)$.

During the course of these studies, we discovered that IEF $_{\mathrm{ga}}$ also binds to a cis-regulatory motif common to virus- and interferon-inducible genes. Interferons are multifunctional proteins that inhibit the spread of viral infection (Reval and Chebath 1986). Indeed, treatment of cells with interferon inhibits the HSV1 growth cycle by blocking IE transcription (Mittnacht et al. 1988; DeStasio and Taylor 1989). We extended these observations by showing that interferon specifically blocks VP16-mediated trans-activation of HSV1 IE genes. Because IEF $_{\text {ga }}$ binds to interferon-inducible genes as well as HSVI IE genes, both of which are regulated by interferon, we speculate that it may help define a network of genes that respond to a specific hormonal signal.

\section{Results}

Purification of $I E F_{g a}$

Rat liver nuclear extracts (RLNE) contain a proteinaceous activity capable of sequence-specific interaction with the GA-rich cis-regulatory motif that occurs between 270 and 290 bp upstream of the HSV1 ICP4 gene (Triezenberg et al. 1988a). Using a combination of chromatographic techniques, coupled with a DNase I footprinting assay, we purified the GA DNA-binding activity, hereafter termed IEF $_{\text {ga }}$. The purification scheme for $\mathrm{IEF}_{\mathrm{ga}}$ is presented in Figure 1. Crude rat liver nuclear

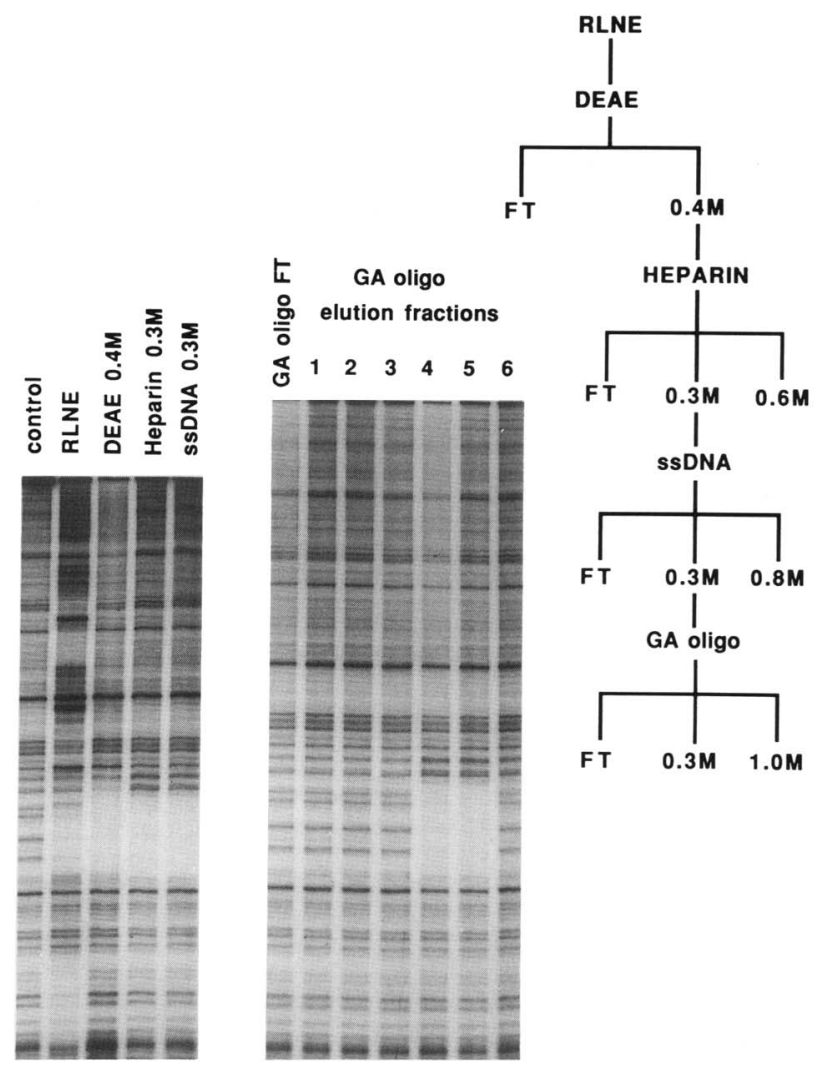

Figure 1. DNase I footprint assays of column fractions during purification of $\mathrm{IEF}_{\mathrm{ga}}$. The purification protocol, beginning with rat liver nuclear extract (RLNE), is depicted as a flow diagram on the right of the figure. DNase I footprint assays are shown on the left. The DNase I pattern obtained in the absence of added protein is shown (left). Remaining lanes show footprints generated with the indicated fractions: (FT) flowthrough; (DEAE) DEAE-cellulose; (heparin) heparin-agarose; (ssDNA) salmon sperm DNA Sepharose; (GA oligo) GA-oligo Sepharose. (Lanes $1-6)$ Fractions eluted from the GA-oligonucleotude affinity column at the following $\mathrm{KCl}$ concentrations: (lanes 1 and 2) 0.1 M KCl; (lanes 3-6) $0.3 \mathrm{M} \mathrm{KCl}$.

extract was applied first to a DEAE-cellulose column at $0.1 \mathrm{M} \mathrm{KCl}(\mathrm{pH} \mathrm{7.6)}$. Approximately one-half of the total protein flowed through the anion exchange column. The DEAE flowthrough fraction contained several DNAbinding activities that recognized $\mathrm{HSVl}$ enhancer and promoter sequences (e.g., SPl, CTF/NF1, C/EBP, and the activity that binds to the TAATGARAT sequences; see Johnson and McKnight 1989/. The DEAE-cellulose column was eluted by a $0.4 \mathrm{M} \mathrm{KCl}$ step and $\mathrm{IEF}_{\mathrm{ga}}$ was localized in the bound fraction. Thus, unlike most sequence-specific DNA-binding proteins, IEF $_{\mathrm{ga}}$ displayed anionic character at neutral $\mathrm{pH}$. The $0.4 \mathrm{M} \mathrm{KCl}$ fraction was dialyzed to $0.1 \mathrm{M} \mathrm{KCl}(\mathrm{pH} 7.6)$, and subsequently was loaded onto a haparin-agarose column. $\mathrm{IEF}_{\mathrm{ga}}$ was retained by this negatively charged resin at 0.1 $\mathrm{M} \mathrm{KCl}$, and was step-eluted at $0.3 \mathrm{M} \mathrm{KCl}$. The observation that $\mathrm{IEF}_{\mathrm{ga}}$ possesses both anionic and cationic properties at neutral $\mathrm{pH}$ suggests that its polypeptide constituent(s) display two oppositely charged domains. 
As a third purification step, the heparin-agarose $0.3 \mathrm{M}$ $\mathrm{KCl}$ pool was dialyzed to $0.1 \mathrm{M} \mathrm{KCl}$ and chromatographed on a matrix created by coupling sonicated salmon sperm DNA to cyanogen bromide $(\mathrm{CNBr})$-activated Sepharose 4B (ssDNA Sepharose). $\mathrm{IEF}_{\mathrm{ga}}$ bound to the ssDNA Sepharose, and was eluted in the $0.3 \mathrm{M} \mathrm{KCl}$ step (Fig. 1). This nonspecific DNA affinity column was followed by three sequential passes over an oligo-specific DNA affinity column bearing the portion of the ICP4 promoter containing the GCGGAA repeats (see see Materials and methods). The ssDNA Sepharose $0.3 \mathrm{~m}$ pool was diluted to $0.1 \mathrm{M} \mathrm{KCl}$, supplemented with competitor DNA (see Materials and methods), and added to the GA oligo-specific resin. Protein was eluted in two steps $(0.3 \mathrm{M}$ and $1.0 \mathrm{M} \mathrm{KCl})$, with IEF $_{\mathrm{ga}}$ confined to the $0.3 \mathrm{M} \mathrm{KCl}$ fraction. This eluent was diluted to $0.1 \mathrm{M} \mathrm{KCl}$, mixed with fresh competitor, and processed through the affinity column two additional times. Results of DNase I footprinting assays corresponding to fractions pooled at various stages of purification, as well as individual fractions from the final pass through the oligo-specific column, are presented in Figure 1.

To examine the profile of polypeptides at various stages of purification, protein samples were concentrated by trichloroacetic acid (TCA) precipitation, and subjected to sodium dodecyl sulfate-polyacrylamide gel electrophoresis (SDS-PAGE). Proteins were visualized by staining with Coomassie brilliant blue. Oligonucleotide affinity fractions $1-6$ in Figure 2 corresponded to the fractions of identical numbers in Figure 1 (where IEF $_{\mathrm{ga}}$ activity was limited to fractions 4 and 5). Judging by the diversity of polypeptides present in the ssDNA Sepharose $0.3 \mathrm{M}$ pool and GA-Sepharose flowthrough, it was clear that the GA affinity column accomplished substantial purification. However, the purification protocol did not lead to the isolation of a single polypeptide (see Fig. 2, lanes 4 and 5). Because our ultimate goal was to identify the polypeptide that specifies $\mathrm{IEF}_{\mathrm{ga}}$ we examined the SDS-PAGE gel in Figure 2 for bands that were enriched by sequential steps of purification. Bands labeled 1, 2, and 3 at the right in Figure 2 represented the most promising candidates. Each band was excised from the gel, the protein was electroeluted, acetone-precipitated, resuspended in $6 \mathrm{M}$ guanidine- $\mathrm{HCl}$, and dialyzed against a DNA-binding buffer /see Materials and methods). Reconstituted protein samples were tested in DNase I footprinting assays as depicted in Figure 3. Lanes 1-3 show footprinting activity achieved with each of the three individually reconstituted polypeptides. Protein from band 2 produced a weak footprint over the GA-rich cis-regulatory element. Because the SDS-PAGE gel was loaded with enough protein to produce $\sim 500$ footprints equivalent to those shown in Figure 1, the footprint achieved by reconstituted band 2 protein was substantially weaker than expected. Therefore, we carried out a mixing experiment using equal portions of the three individually recovered bands. As shown in Figure 3, the mixture of the three separate polypeptides yielded a significantly stronger reconstitution of $\mathrm{IEF}_{\mathrm{ga}}$ activity than did any of the single polypep-

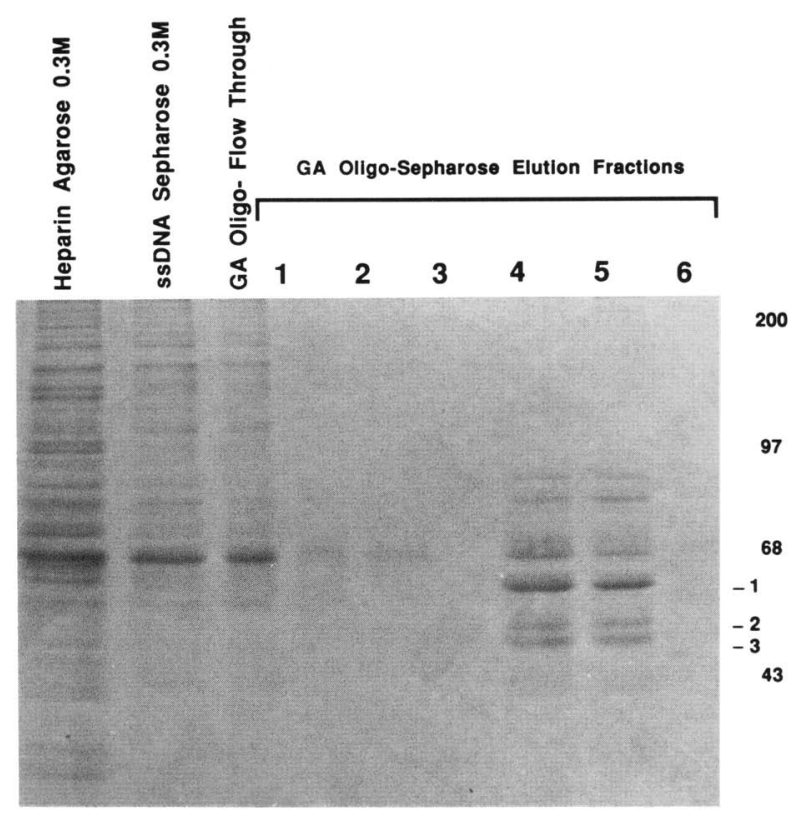

Figure 2. SDS-PAGE of protein present in fractions at selected stages of purification of IEF $_{\mathrm{ga}}$. Protein samples were concentrated by TCA precipitation, resuspended in SDS sample buffer, heated for $5 \mathrm{~min}$ at $65^{\circ} \mathrm{C}$, and loaded onto a $10 \%$ SDSpolyacrylamide gel. Protein bands were visualized by staining with Coomassie brilliant blue. The numbers at the right represent the positions of molecular weight standards (in $\mathrm{kD})$, and 1 , 2 , and 3 are the polypeptide bands that were excised and tested for $\mathrm{IEF}_{\mathrm{ga}}$ binding activity. GA-oligo affinity fractions (lanes 1-6) correspond to the fractions of the same numbers in Fig. 1.

tides. The ability of pairwise combinations of protein bands 1, 2, and 3 to bind to the GA-rich element was not tested.

Having observed a complex pattern of proteins eluting from the GA affinity column (Fig. 2), and an apparent requirement of at least two polypeptides to achieve reconstitution (Fig. 3), we undertook a second approach to identify the polypeptides involved in GA binding. Complementary, synthetic oligonucleotides bearing the portion of the ICP4 promoter containing the GCGGAA repeats were phosphorylated, annealed, and catenated by ligation, yielding a collection of molecules consisting of from 5 to 10 repeats of the original monomers /see Materials and methods). The catenated probe was then photobiotinylated and incubated with the $0.3 \mathrm{M} \mathrm{KCl}$ fraction from the ssDNA Sepharose column. The resulting complexes were chromatographed on an affinity column consisting of strepavidin coupled to agarose (Franza et al. 1987; Sturm et al. 1987). After appropriate binding and washing, the column matrix was boiled in SDS sample buffer, and solubilized material was loaded onto an SDS-PAGE gel. Results of this experiment are presented in Figure 4. Lane 1 shows proteins derived from an experiment in which no DNA was included in the binding reaction, whereas lane 2 shows proteins derived after use of a heterologous DNA probe (see Materials and 


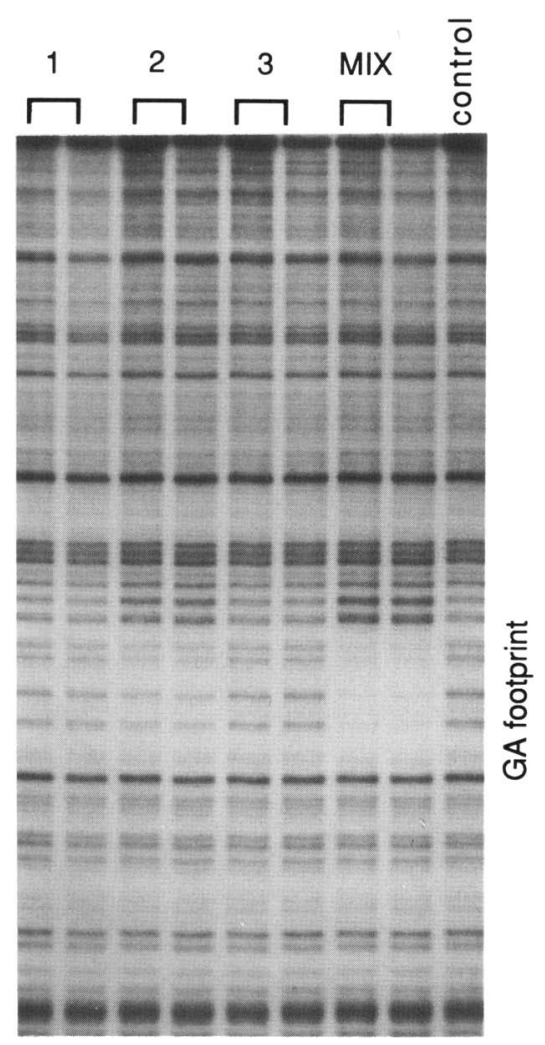

Figure 3. DNase I footprint assays performed with reconstituted protein samples. Individual protein bands $(1,2$, and 3 in Fig. 2) were excised from the gel, electroeluted, acetone-precipitated, resuspended in $6 \mathrm{M}$ guanidine $-\mathrm{HCl}$, and dialyzed against $2 \times$ footprinting buffer (see Materials and methods). In the case where the mix of the three proteins was tested, equivalent aliquots of proteins from bands 1,2 , and 3 were combined after resuspension in guanidine- $\mathrm{HCl}$, and dialyzed as a mix. Samples were then used in DNase I footprinting reactions as described in Materials and methods. For each isolated band, as well as for the mixture of the three, two conditions were used; the first lane of each pair lacked competitor poly[d(I-C)], and the second lane contained $0.1 \mu \mathrm{g}$ of poly[d(I-C)] in the binding reaction.

methods). Thus, proteins present in lanes 1 and 2 of Figure 4 represented either a collection of nonspecifically precipitated proteins, or contaminants of the gel system. In lane 3, the catenated GCGGAA probe was used to detect polypeptides that bound specifically to the GA sequence. Four polypeptide bands (labeled a-d), not evident in the control lanes ( 1 and 2 ), were observed under these conditions. Consistent with results presented in Figure 2, the protein bands again ranged in molecular weight between $43 \mathrm{kD}$ and $68 \mathrm{kD}$. Tentatively, we conclude that three of these bands correspond to the three polypeptides that, when mixed, reconstituted $\mathrm{IEF}_{\mathrm{ga}}$ binding activity (Fig. 3).

\section{Interaction between $I E F_{g a}$ and cis-regulatory sequences of cellular genes}

The occurrence of $\mathrm{IEF}_{\mathrm{ga}}$ in uninfected cells is consistent with its involvement in cellular gene regulation. If this is true, the existence of $\mathrm{IEF}_{\mathrm{ga}}$ binding sites associated with cellular genes might provide a clue as to the nature of its function within uninfected cells. For example, does $\mathrm{IEF}_{\mathrm{ga}}$ bind to and regulate a large family of genes, or does it tie together a more selected network of cellular gene regulation?

Pursuing this line of thinking, we noticed sequence similarity between the GA-rich repeats of the ICP4 gene and regulatory regions common to virus- and interferoninducible genes. Repeats related to the hexanucleotide sequence, GAAANN, have been shown to constitute integral cis-regulatory elements necessary for appropriate expression of certain virus- and interferon-inducible genes (Ryals et al. 1985; Kuhl et al. 1987; Hug et al. 1988). Weissmann and colleagues carried out extensive studies on these cell-derived, cis-regulatory sequences that bear relatedness to the GA-rich element of HSV IE genes (Kuhl et al. 1987; F.-D. Kuhl and C. Weissmann, pers. comm.). In one series of experiments, catenated repeats of two hexanucleotide sequences, GAAAGT and GAAACG, were prepared from synthetic oligonucleotides. These isolated elements were inserted between the SV40 enhancer and the rabbit $\beta$-globin gene, and tested in transient transfection assays in the presence or absence of interferon. Four repeats of the GAAAGT element [tetra(GAAAGT)] rendered the SV40- $\beta$-globin construct responsive to interferon. In contrast, four repeats of the GAAACG element [tetra|GAAACG|] elevated the basal level of globin transcription, yet did not mediate response to interferon.

To test whether these GA-rich cellular sequences might be recognized by $\mathrm{IEF}_{\mathrm{ga}}$, we carried out DNase I

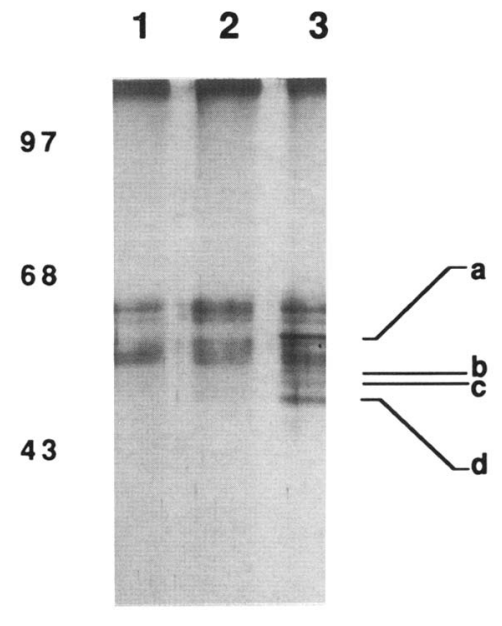

Figure 4. SDS-PAGE of proteins complexed with photobiotinylated, catenated DNA probes. Protein extracts were incubated at $4^{\circ} \mathrm{C}$ with either no DNA (lane 1), a nonspecific (lane 2) or a GA-specific (lane 3) catenated, photobiotinylated DNA probe. Then complexes were bound to strepavidin agarose, the matrix was washed, and precipitated proteins were eluted from the matrix by boiling in SDS sample buffer. Samples were electrophoresed on a $10 \%$ polyacrylamide gel, and proteins were visualized by silver staining. The numbers at left indicate positions of molecular weight standards in kilodaltons. Protein bands specific to lane 3 are shown (a, b, c, and d). 
footprinting assays. Radiolabeled DNA fragments containing the tetra(GAAAGT) and tetra(GAAACG) repeats (generously provided by F.-D. Kuhl and C. Weissmann), were incubated with purified $\mathrm{IEG}_{\mathrm{ga}}$ exposed to DNase I, and electrophoresed on sequencing gels. As shown in Figure 5, IEF ga $_{\text {a }}$ bound to the DNA fragment harboring the tetra(GAAACG) repeat, but not to the fragment containing the tetra(GAAAGT) repeat. Maxam and Gilbert (1980) chemical sequencing reactions were electrophoresed adjacent to the footprinting reactions, revealing coincidence between the locations of the DNase I footprint and the GAAACG repeats. Complete DNase I protection of the tetra(GAAACG) repeats was achieved after addition of two arbitrary units of protein, the same amount required for complete protection of the GA-rich element from the ICP4 gene of HSV1.

If the aforementioned studies on the binding of IEF $_{\mathrm{ga}}$ to the two GAAANN hexanucleotide repeats are a reflection of how these components function in living cells, then it might be expected that a consistency between protein-DNA interaction in vitro and transcriptional activation in vivo would be observed. As mentioned previously, the tetra(GAAAGT) and
tetra(GAAACG) repeats act differently when inserted between the SV40 enhancer and the rabbit $\beta$-globin gene. Because $I_{E F}$ binding was restricted to the GAAACG motif, we anticipated that the $\operatorname{IEF}_{\mathrm{ga}}$-binding site native to the HSVl ICP4 gene would, when placed between the SV40 enhancer and rabbit $\beta$-globin gene, behave like the tetra(GAAACG) repeat.

Complementary oligonucleotides corresponding to the $\mathrm{IEF}_{\mathrm{ga}}$ binding site from the HSVI ICP4 gene were annealed and inserted between the SV40 enhancer and the rabbit $\beta$-globin gene in the same position as the tetra(GAAANN) elements (see Materials and methods). This new construct, termed GA- $\beta$ G, was tested in transient transfection assays in parallel with tests of the parental template (SV40- $\beta$ G) and the two tetra (GAAANN) templates (Fig. 6). Transcription was monitored by primer extension using an oligonucleotide complementary to rabbit $\beta$-globin mRNA (see Materials and methods). Each transfection assay included a second template consisting of the SV40 early region linked to the HSV thymidine kinase gene (SV40tk). Transcription from this second template was monitored by primer extension using an oligonucleotide complementary to $t k$
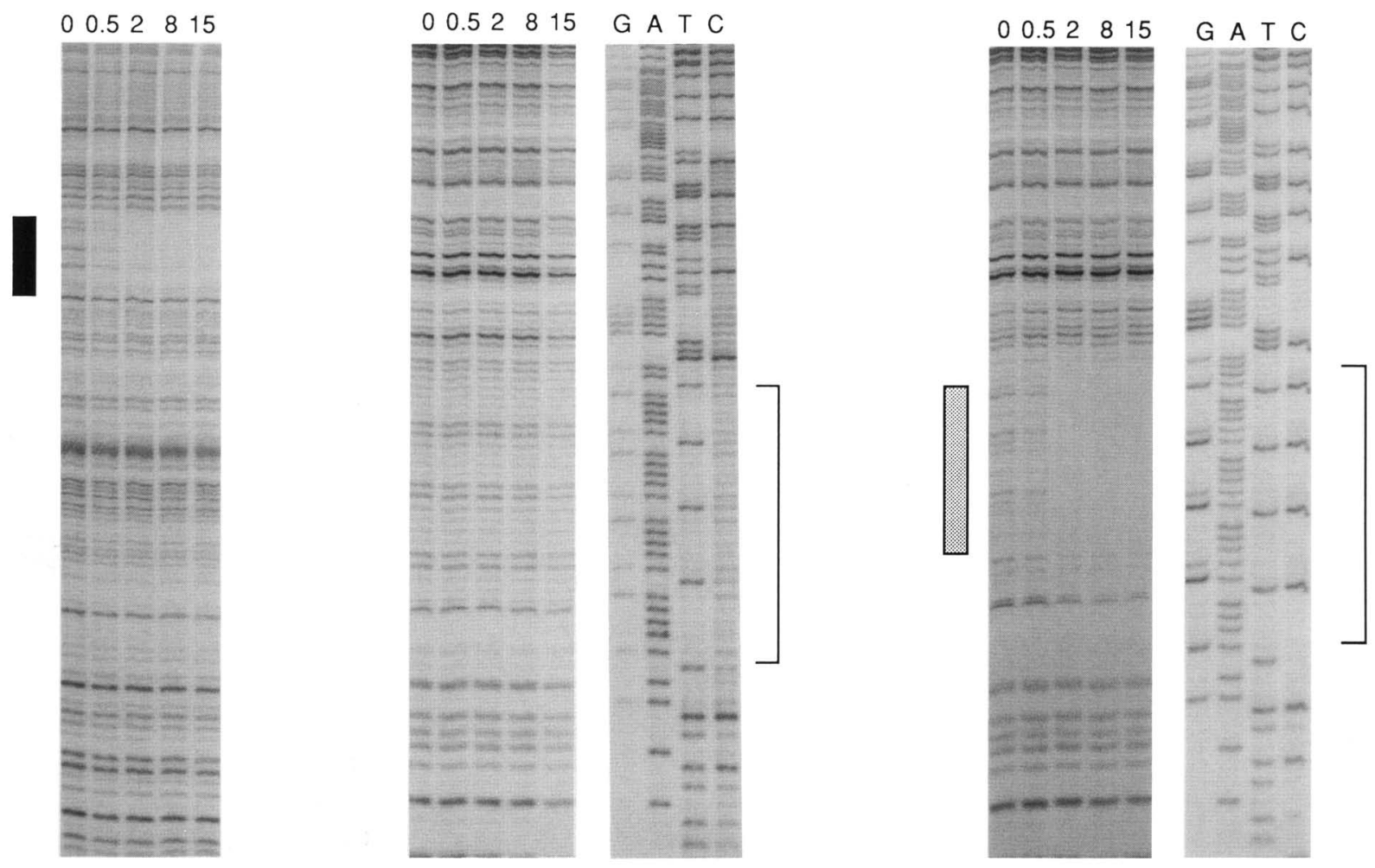

Figure 5. DNase I footprint assays performed on sequences derived from vinus- and interferon-inducible genes. $(A)$ Footprint reactions using increasing concentrations of affinity-purified $\mathrm{IEF}_{\mathrm{ga}}$ on the GA regulatory element native to the ICP4 gene are shown. $(B$ and $C)$ Results of DNase I footprint assays and chemical sequencing reactions on GAAANN elements common to virus- and interferon-inducible promoters are shown. $(B)$ Results of experiments using the tetra(GAAAGT) construct; $(C)$ results using the tetra(GAAACG) construct (see Materials and methods). Numbers above gel lanes refer to the amount of IEF $_{\mathrm{ga}}$ protein added, expressed in arbitrary units. Filled boxes indicate the region of the footprint. 


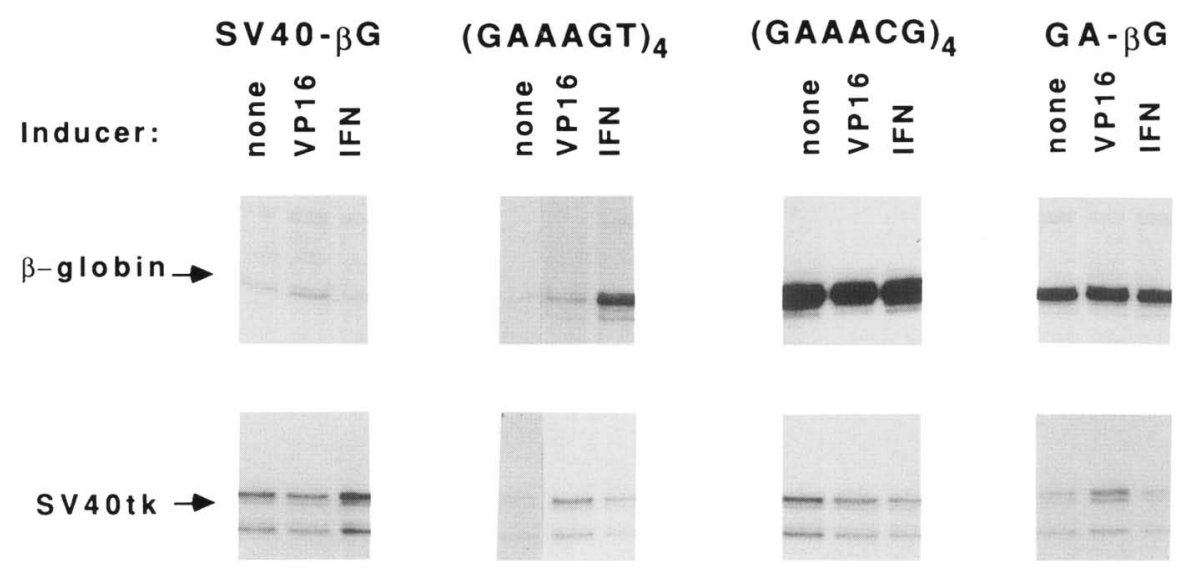

Figure 6. Effects of VP16 and interferon on expression from various transcriptional regulatory elements. Experimental and control templates $(2 \mu \mathrm{g})$ were transfected into mouse L cells. All plates were cotransfected with a second plasmid (l $\mu \mathrm{g})$ containing the SV40 enhancer fused to the mRNA coding region of the HSVtk gene (SV40tk). Transcription of SV40tk was not affected by either VP16 or interferon, and served as an internal control for transfection efficiency and RNA recovery. VP16 induction was achieved by cotransfection with $2 \mu \mathrm{g}$ of a plasmid containing the MSV LTR fused to the mRNA coding segment of the HSVl VP16 gene (MSVP16). Interferon induction was performed by adding $1000 \mathrm{IU} / \mathrm{ml}$ of mouse $\alpha, \beta$-interferon (IFN) during the terminal $18 \mathrm{hr}$ of culture. The plasmid SV40- $\beta$ G contains the SV40 enhancer linked to the rabbit $\beta$-globin gene. (GAAAGT) ${ }_{4}$ and (GAAACG) ${ }_{4}$ are derivatives of SV40- $\beta$ G containing oligomerized sequences common to virus- and interferon-inducible genes, and correspond to tetra(GAAAGT) and tetra(GAAACG), respectively (see text). GA- $\beta$ G is a derivative of SV40- $\beta$ G containing two copies of the GA-rich cis-regulatory element of the HSV1 ICP4 gene. After transfection and RNA isolation, primer extension reactions were performed to quantitate steadystate levels of RNA synthesized from the test and internal control templates. Test and control RNAs were distinguished by the use of two synthetic oligonucleotide primers. One primer hybridized to rabbit $\beta$-globin mRNA, and yielded a 78 -nucleotide extension product (indicated by $\beta$-globin and an arrow in the figure). The second primer hybridized to tk mRNA, and was used to quantitate transcription from the SV40tk construct (indicated by SV40tk and an arrow in the figure).

mRNA (Graves et al. 1986), and served as an internal control for transfection efficiency and RNA recovery. Transfection assays were carried out under three conditions: basal, without added inducing agent; interferon induced, with $1000 \mathrm{IU} / \mathrm{ml}$ of mouse $\alpha, \beta$ interferon added during the terminal $18 \mathrm{hr}$ of cell growth; and VPl6 induced, with addition of a plasmid-borne expression vector that encoded intact VP16 protein (MSVP16; Triezenberg et al. 1988a).

The results of these transient transfection assays are presented in Figure 6. When expression of the four templates was compared in the absence of inducing agents, both GA- $\beta$ G and (GAAACG) ${ }_{4}$ produced a higher level of globin mRNA than (GAAAGT) ${ }_{4}$, which was equivalent in relative expression efficiency to the parental template (SV40- $\beta \mathrm{G})$. The only template that produced a higher level of globin mRNA under conditions of induction by mouse $\alpha, \beta$ interferon was $\left(\mathrm{GAAAGT}_{4}\right.$. Finally, none of the templates responded to induction by VP16.

\section{Interferon blocks VP16-mediated activation of HSV1 IE gene expression}

Having noticed that $\operatorname{IEF}_{\mathrm{ga}}$ bound to a cis-regulatory element common to interferon-inducible genes (GAAACG), we wondered whether interferon would affect transcription of HSVI IE genes. Indeed, several independent studies have already shown that treatment of cultured cells with interferon prior to infection with HSVl impedes transcription of IE genes (Mittnacht et al.
1988; DeStasio and Taylor 1989|. Because VP16 activation of IE transcription depends, in part, on an intact $\mathrm{IEF}_{\mathrm{ga}}$-binding site, we hypothesized that interferon might impinge on IE gene expression by inhibiting VP16 induction. To test this possibility, cultured mouse cells were cotransfected with two plasmids: ICP4tk, a target plasmid for VP16 activation consisting of the upstream regulatory DNA sequences of the HSV1 ICP4 gene linked to the mRNA coding segment of the HSV1 tk gene; and SV40tk, an internal reference plasmid consisting of the SV40 early region linked to the HSV1 $t k$ gene. Parallel culture dishes transfected with these two test templates also were transfected with a third plasmid termed MSVP16 (Triezenberg et al. 1988a). MSVP16 is an expression vector capable of encoding intact VP16 protein. One day after transfection, cells were fed with either fresh culture medium, or medium containing $1000 \mathrm{IU} / \mathrm{ml}$ of mouse $\alpha, \beta$ interferon.

As has been observed in previous studies (Triezenberg et al. 1988a), addition of MSVP16 led to a specific activation of expression from the ICP4tk template (Fig. 7). However, when interferon was added during the terminal $18 \mathrm{hr}$ of culture, transcription from the ICP4tk template was reduced to a near-basal level. The inhibitory effects of interferon on transcription from the ICP4 promoter were not observed in the absence of VP16. Moreover, interferon exerted little or no effect on transcription from the SV40tk template.

Activation of the HSVI ICP4 gene by VP16 is dependent on two cis-regulatory motifs, TAATGARAT 


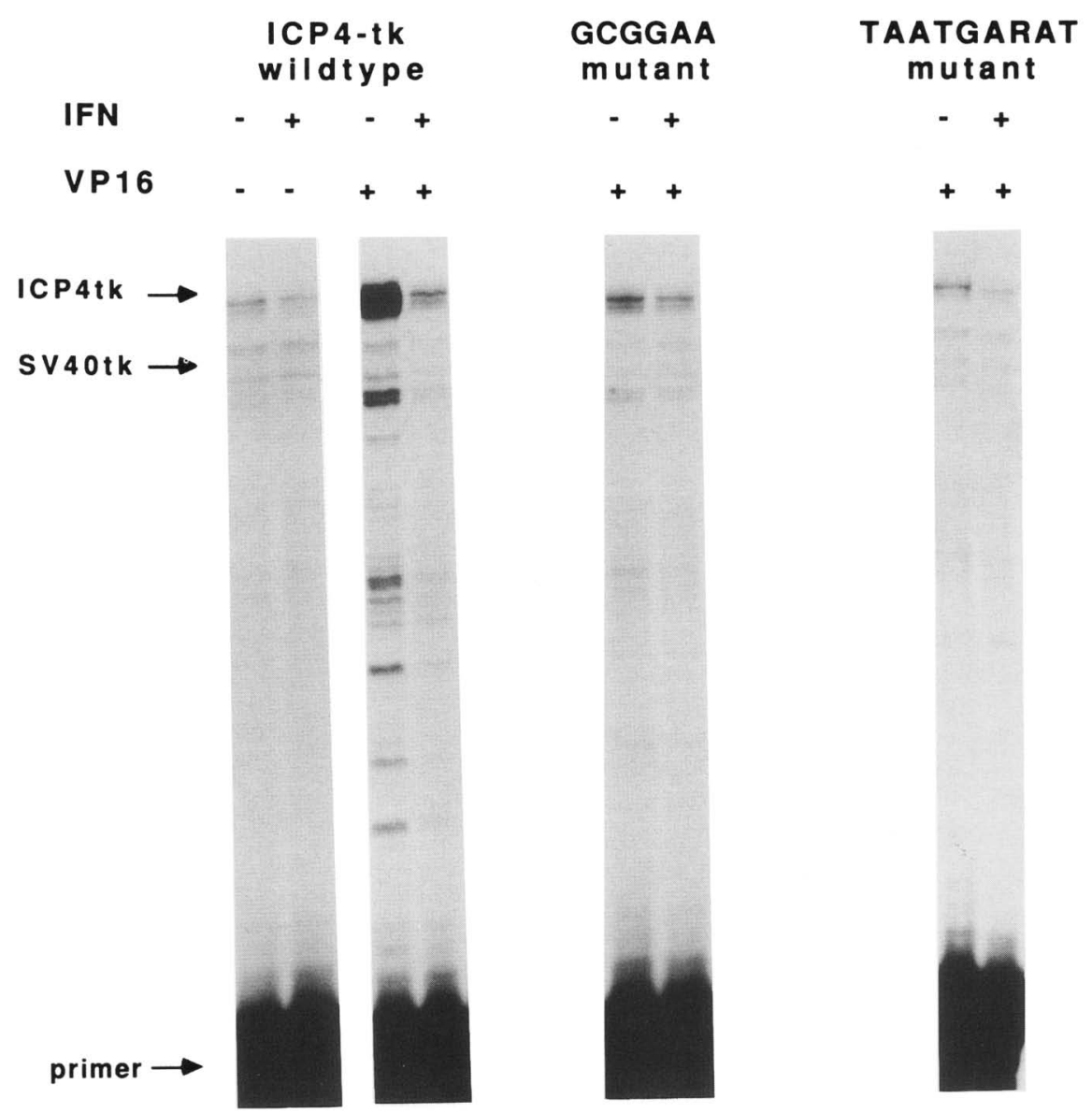

Figure 7. Effect of interferon and VP16 on expression from the native and mutant ICP4 regulatory regions. Experimental (ICP4tk wild type, GCGGAA mutant, and TAATGARAT mutant) and control (SV40tk) plasmids (2 $\mu \mathrm{g}$ ) were transfected into mouse L cells, under one of three conditions: no added inducer; cotransfection with the MSVP16 plasmid (VP16); or treatment with 1000 IU/ml mouse $\alpha, \beta$ interferon $18 \mathrm{hr}$ prior to harvest (IFN). Primer extension assays were performed to quantitate steady-state levels of tk mRNA. ICP4tk extension products (top arrow), SV40tk extension product (middle arrow), and ${ }^{32}$ P-labeled tk primer (bottom arrow) are shown.

(Mackem and Roizman 1982a,b; Cordingley et al. 1983; Kristsie and Roizman 1984; Gaffney et al. 1985; Bzik and Preston 1986; O'Hare and Hayward 1987; Triezenberg et al. 1988a) and GA (Triezenberg et al. 1988a). When the function of these cis-regulatory motifs is eliminated, IE gene expression proceeds at a considerably lower 'basal' level that relies on a series of Spl-binding sites (Jones and Tiian 1985; Triezenberg et al. 1988a). To determine whether interferon treatment specifically blocked VP16-mediated trans-activation, we carried out transient transfection assays using two mutated forms of the ICP4tk test plasmid. One mutant bore clustered base changes in the GA-rich cis-regulatory region, and the other was altered at all three TAATGARAT elements normally present upstream of the ICP4 gene (Triezenberg et al. 1988a). When either of these mutants was transfected into mouse cells along with MSVP16, a considerably lower level of transcription was observed (Fig. 7). Importantly, interferon treatment failed to eliminate this basal level of transcription.

\section{Discussion}

We described the purification of a DNA-binding activity, termed IEF $\mathrm{ga}_{\mathrm{g}}$ that is capable of specific in vitro recognition of the GCGGAA cis-regulatory element associated with the HSVI ICP4 gene. The GA-rich element is one of two cis-regulatory sequences necessary for activation of IE gene transcription by VP16 Mackem and Roizman 1982a,b; Cordingley et al. 1983; Kristie and Roizman 1984; Gaffney et al. 1985; Bzik and Preston 1986; O'Hare and Hayward 1987; Triezenberg et al. 1988a). Several pieces of evidence presented in this report suggest that more than one polypeptide may be required for $\mathrm{IEF}_{\mathrm{ga}}$ binding activity. Two separate purification procedures led to the isolation of a collection of polypeptides ranging between 43 and $68 \mathrm{kD}$ (Figs. 2 and 4). Extensive studies on two proto-oncogene products, FOS and JUN, offer a precedent for the participation of multiple polypeptides in a single DNA-binding activity. Highly purified preparations of the HeLa cell transcription factor 
AP1, contain several polypeptides (Lee et al. 1987; Rauscher et al. 1988a). One of the polypeptides in the AP1 collection is the product of the c-jun proto-oncogene (Bohmann et al. 1987). On its own, the JUN polypeptide is capable of sequence-specific interaction with the canonical AP1-binding site. However, immunological studies have revealed that FOS and FOS-related antigens are present in APl preparations (Franza et al. 1988; Rauscher et al. 1988b). Moreover, FOS and JUN polypeptides form a complex that binds to the canonical APl site with greater affinity than the JUN polypeptide alone (Halazonetis et al. 1988; Nakabeppu et al. 1988; Rauscher et al. 1988c). With respect to $\mathrm{IEF}_{\mathrm{ga} \text {, }}$ it is thus notable that one polypeptide (band 2) accomplished weak sequence-specific DNA binding, and that addition of copurifying proteins improved footprinting activity considerably (Fig. 3).

Unlike other multicomponent DNA-binding activities that dissociate when subjected to conventional chromatography (e.g., Chodosh et al. 1988), the IEF $_{\text {ga }}$ polypeptides remained associated throughout our purification scheme. This observation may indicate that these polypeptides comprise a single protein that has been proteolyzed during purification, yet remains associated until subjected to SDS-PAGE. Alternatively, this collection of associated proteins may represent several different gene products that form a stable, multisubunit protein. Resolution of these various possibilities will require molecular reagents such as $\mathrm{IEF}_{\mathrm{ga}}$-specific antibodies and recombinant DNA clones of the gene(s) encoding IEF $_{\mathrm{ga}}$.

Beyond offering a biochemical description of the polypeptide constituents of $\mathrm{IEF}_{\mathrm{ga}}$ this report also describes experiments undertaken to investigate potential roles for this activity in the context of cellular gene regulation. We outlined two observations that raise the possibility that $\mathrm{IEF}_{\mathrm{ga}}$ may play a role in mediating cellular response to interferon. First, we observed that $\mathrm{IEF}_{\mathrm{ga}}$ binds to an oligomerized from of a cis-regulatory element common to interferon responsive genes. Second, we found that interferon selectively blocks trans-activation of IE genes by VP16. Because interferon appears to inhibit IE transcription by disrupting VP16 action, and because VP16 induction is dependent upon the $\mathrm{IEF}_{\mathrm{ga}}$ binding site, we speculate that $\mathrm{IEF}_{\mathrm{ga}}$ may play a dedicated role in mediating interferon response. The observation that interferon selectively blocks VP16-mediated transcription, perhaps in a manner involving $I E F_{\mathrm{ga} /}$ raises the possibility that interferon action on cellular gene expression might involve selective gene repression (as well as its documented capacity to activate gene expression).

One of the more interesting interferon-induced genes, the mouse $M x$ gene, encodes a protein that establishes an antiviral state. $\mathrm{Mx}^{+}$mice are resistant to doses of influenza virus that are lethal to $\mathrm{Mx}^{-}$strains (Lindenmann 1962). Staeheli et al. (1986) isolated the gene encoding the mouse $M x$ protein, and have shown that transformed cells constitutively expressing $M x$ are resistant to infection by influenza virus. The portion of the promoter that allows both virus and interferon induction of
$M x$ gene transcription contains the inverse complement of the GAAACG motif (Hug et al. 1988). Ironically, it may be that $I_{\mathrm{ga}}$ is used by the cell to induce synthesis of antiviral proteins, and also is employed by HSVl to facilitate activation of IE gene transcription by VP16.

As tetra(GAAACG) and tetra(GAAAGT) are functionally dissimilar cis-regulatory elements (Kuhl et al. 1987; F.-D. Kuhl and C. Weissmann, pers. comm.; Fig. 6), it may be notable that $\mathrm{IEF}_{\mathrm{ga}}$ recognizes only tetra(GAAACG). Perhaps $I_{\text {IE }}$ collaborates in vivo with a second cellular activity that recognizes an interferoninducible form of the GAAANN consensus (e.g., GAAAGT). In vitro footprinting experiments have shown that $\mathrm{IEF}_{\mathrm{ga}}$ does not bind to a single, isolated GArich hexanucleotide (K. LaMarco and S. McKnight, unpubl.). Although the hexanucleotide consensus of the $\mathrm{IEF}_{\mathrm{g}_{\mathrm{a}}}$ binding site is tandemly repeated in the ICP4 gene, only a single copy occurs in cellular genes that are induced by interferon (e.g., see Table 1, Hug et al. 1989). Stabilization of $\mathrm{IEF}_{\mathrm{ga}}$ binding to a single GAAACG hexanucleotide might require additional interactions among proteins bound at an adjacent GAAAGT site.

Previous studies (Triezenberg et al. 1988a), confirmed by results presented herein (Fig. 7) show that deletion of the GA-rich repeat from the ICP4 promoter substantially reduces the level of VP16-induced transcription. Such results imply that VP16 function is dependent on the GA element. Moreover, when clustered point mutations were introduced into each of the three TAATGARAT elements of the ICP4 promoter, the remaining GA-rich motif was observed to function independently to support a low level of VP16-activated transcription (Triezenberg et al. 1988a). In contrast, results in Figure 6 reveal that when the $\operatorname{IEF}_{\mathrm{ga}}$ binding site is removed from the context of the ICP4 regulatory region, and placed between the SV40 enhancer and the $\beta$-globin gene, it did not confer responsiveness to VP16. Rather, it led to an elevation in the basal expression of the SV40- $\beta$-globin construct. Because TAATGARAT can confer VP16 responsiveness after being removed from the ICP4 regulatory region (Gaffney et al. 1985), it may represent the more immediate site of VP16 action. Biochemical experiments are consistent with this interpretation. VP16 is capable of forming a ternary complex with TAATGARAT and OTF, (Gerster and Roeder 1988; O'Hare and Goding 1988), but not with the GA-rich cis-regulatory element and purified $\operatorname{IEF}_{\mathrm{ga}} \mid \mathrm{C}$. Vinson and $\mathrm{K}$. LaMarco, unpubl.). It appears that the GA-rich element and its cognate DNA-binding activity $\left(\mathrm{IEF}_{\mathrm{ga}}\right)$ play an integral role in facilitating VP16-mediated transcriptional activation without representing an immediate site of VP16 occupancy.

A similar, facilitating role might characterize the action of $\mathrm{IEF}_{\mathrm{ga}}$ on interferon-inducible genes. Tetra (GAAACG), which binds IEF $_{\text {ga }}$ does not confer responsiveness to interferon when oligomerized and appended onto a heterologous gene. In contrast, when treated in an identical manner, tetra(GAAAGT) retains its interferon inducibility. The concept that interferon induction may rely on a combination of virus-inducible and constitu- 
tive transcriptional activating elements has been suggested previously (Goodbourn et al. 1986; Kuhl et al. 1987; Keller and Maniatis 1988).

In closing, we emphasize that we have not yet proven that the GA-rich cis-elements common to HSVl IE genes, virus- and interferon-inducible genes, all use IEF $_{\text {ga }}$ as a trans-activator. Nor have we deciphered the role that $\mathrm{IEF}_{\mathrm{ga}}$ plays in expression of these genes. However, if $\mathrm{IEF}_{\mathbf{g a}}$ does serve to regulate transcription via these related elements, it is intriguing that the identical cis-and trans-regulatory system is used by genes that are modulated by interferon in reciprocal fashions. This observation may suggest that $\mathrm{IEF}_{\mathrm{ga}}$ is not a generic transcription factor. Rather, it appears to be involved in the regulation of genes that are modified under specific hormonal conditions. A more complete understanding of $\mathrm{IEF}_{\mathrm{ga}}$ function should emerge upon availability of specific antibodies, and cDNA clones encoding the polypeptides described in this report. Efforts to develop such molecular reagents are underway.

\section{Materials and methods}

Plasmids used in transient transfection assays

Composition of ICP4tk (pSJT703), which contains the regulatory region of the HSV1 ICP4 gene linked to the mRNA coding segment of the HSV $t k$ structural gene, has been described previously (Triezenberg et al. 1988a). Mutated variants of ICP4tk lacking either the GA-rich regulatory element, or all three TAATGARAT sites have also been described (Triezenberg et al. 1988a). Plasmids containing regulatory sequences from virusand interferon-inducible genes, positioned between the SV40 enhancer and the rabbit $\beta$-globin gene [39P, tetra|GAAACG] and 61P, tetra(GAAAGT)|, were obtained from F.-D. Kuhl and C. Weissmann, and have been described previously (Kuhl et al. 1987). The plasmid containing the ICP4 GA-rich repeat region inserted between the SV40 enhancer and the rabbit $\beta$-globin gene was constructed in two steps. The parent plasmid was $39 \mathrm{P}$ (Kuhl et al. 1987), which contained four repeats of the interferon- $\alpha_{1}$ repA inserted between the SV40 enhancer and the rabbit $\beta$-globin gene, was digested with $\mathrm{ClaI}$ and HindIII, allowing liberation of the repA sequences. The following complementary, synthetic oligonucleotides, which contained ClaI and HindIII 'sticky' ends, and an internal $\mathrm{XbaI}$ site, were phosphorylated, annealed, and inserted into the vector fragment resulting from ClaI-HindIII digested of 39P:

5' - CGATGTCTAGAGA - 3'

3'-TACAGATCTCTTCGA-5'

The resulting plasmid, termed SV40- $\beta$ G, still contained the SV40 enhancer linked to the rabbit $\beta$-globin gene. This plasmid was used as a control in transient transfection experiments for basal levels of transcription. A second set of complementary, synthetic oligonucleotides containing the ICP4 GA-rich repeat and $\mathrm{XbaI}$ ends, were phosphorylated, annealed, and ligated into SV40- $\beta$ G that had been cleaved with $X b a I$. This plasmid was termed GA- $\beta$ G. Maxam-Gilbert (1980) chemical sequencing showed that GA- $\beta$ G contains two copies of the original GA repeat (see below). Footprinting assays using purified $\operatorname{IEF}_{\mathrm{ga}}$ showed specific binding to the two GA repeats /data not shown).

5'-CTAGAGCGGAACGGAAGCGGAAAC - 3'

3'-TCGCCTTGCCTTCGCCTTTGGATC-5'
Transient transfection assays

Plasmid DNA $(2 \mu \mathrm{g})$ was transfected into mouse $\mathrm{L} \mathrm{tk}^{-}$cells on 60-mm dishes by the DEAE-Dextran/DMSO method (Lopata et al. 1984). Transcription from a plasmid bearing the SV40 early region driving the tk structural gene (SV40tk), which was not affected by the presence of either VP16 or interferon, was monitored as an internal control. For VP16 induction, cells were cotransfected with $2 \mu \mathrm{g}$ of a plasmid containing the VP16 structural gene driven by the MSV LTR (MSVP16; Triezenberg et al. 1988a). Interferon induction was achieved by treating cells with $1000 \mathrm{IU} / \mathrm{ml}$ interferon (mouse $\alpha, \beta$; Sigma) $18 \mathrm{hr}$ prior to harvest. RNA was harvested $40 \mathrm{hr}$ post-transfection, and was analyzed by primer extension (Eisenberg et al. 1985) using one of two synthetic, oligonucleotide primers. The first primer was complementary to the sequences between +56 and +80 relative to the tk mRNA cap site. The major tk extension products measured between 78 and 81 bases, and resulted from transcription of the test plasmid. Extension of the tk primer from SV40tk-derived RNA yielded a pair of smaller extension products that were easily distinguished from those derived from the ICP4 template. The second oligonucleotide primer was complementary to sequences within the $\beta$-globin gene between +53 and +78 relative to the rabbit $\beta$-globin mRNA cap site (Efstratiadis et al. 1977), and the major primer extension product was 78 bases.

\section{Preparation of DNA fragments for DNase I footprinting}

ICP4 regulatory sequences were excised by SalI-BamHI digestion of the parent plasmid, pSJT703 (Triezenberg et al. 1988a). Following Sall digestion, the DNA was treated with calf intestinal phosphatase (Boehringer-Mannheim), then labeled with [ $\gamma^{-32}$ P]ATP (3000 Ci/mM, Amersham) using T4 polynucleotide kinase (New England Biolabs). Subsequent BamHI digestion yielded a 400 -bp probe that was purified by agarose gel electrophoresis. Plasmids bearing the interferon-derived hexanucleotide repeats were generously provided by F.-D. Kuhl and C. Weissmann (Kuhl et al. 1987). Following EcoRI digestion, plasmid DNA was treated with calf intestinal phosphatase, and labeled with $\left[\gamma^{-32} \mathrm{P}\right] \mathrm{ATP}$ and T4 polynucleotide kinase. The labeled DNA was subsequently cut with BamHI and purified by agarose gel electrophoresis, yielding a fragment of $\sim 600 \mathrm{bp}$.

\section{DNase 1 footprinting}

DNase I footprinting assays (Galas and Schmitz 1978) were performed as described by Johnson et al. (1987). Column fractions were added to a 50- $\mu$ l DNA-binding reaction containing $25 \mathrm{~mm}$ Tris- $\mathrm{HCl}(\mathrm{pH}$ 7.9), $3 \mathrm{~mm} \mathrm{MgCl}, 10 \%$ glycerol, $0.5 \mathrm{~mm}$ EDTA, $0.5 \mathrm{~mm}$ DTT, $0.1-1.0 \mu \mathrm{g}$ of poly[d(I-C) (Boeringer-Mannheim), and an end-labeled DNA fragment $(1-5 \mathrm{fM})$. The final salt concentration was determined by the ionic strength of the protein extract, and varied between $40 \mathrm{~mm}$ and $80 \mathrm{mM}$. After incubation on ice for $10 \mathrm{~min}$, the reaction mixtures were transferred to a $22^{\circ} \mathrm{C}$ water bath for $2 \mathrm{~min}$. Five microliters of DNase I (Worthington), freshly diluted with $25 \mathrm{~mm} \mathrm{CaCl}_{2}$, was added to the reaction mixture. The reaction was terminated $60 \mathrm{sec}$ later by the addition of $100 \mu$ l of DNase I stop buffer (1\% SDS, $100 \mu \mathrm{g} / \mathrm{ml}$ tRNA, $200 \mathrm{mM} \mathrm{NaCl}, 20 \mathrm{mM}$ EDTA, and $200 \mu \mathrm{g} / \mathrm{ml}$ proteinase $\mathrm{K}$ ). Proteinase $\mathrm{K}$ digestion was allowed to proceed for $20 \mathrm{~min}$ at $50^{\circ} \mathrm{C}$. DNA was separated from protein by phenolchloroform extraction, recovered by ethanol precipitation, and boiled for $3 \mathrm{~min}$ in $3 \mu \mathrm{l}$ of $99 \%$ formamide containing bromophenol blue and xylene cyanol and tracking dyes. The samples were electrophoresed on $7 \%$ polyacrylamide $-8 \mathrm{M}$ urea gels, 
which were subsequently dried and autoradiographed using Kodak XAR-5 film.

\section{Protein fractionation}

Crude rat liver nuclear extracts (RLNE) were prepared as described (Triezenberg et al. 1988a), except that $0.5 \%$ Nonidet P-40 (NP-40, Sigma) was included in the nuclear lysis buffer. All procedures were carried out at $0-4^{\circ} \mathrm{C}$. GA-binding activity was followed throughout the purification by DNase I footprinting, using a SalI-BamHI fragment of the HSVI ICP4 promoter as the probe. The standard column buffer consisted of HGEDK [20 mM HEPES (pH 7.6), 10\% glycerol, 0.1\% NP-40, 1 mM EDTA; $1 \mathrm{mM}$ DTT, and $\mathrm{KCl}$ varied as appropriatej. RLNE (200 mg protein) was loaded onto a DEAE-cellulose column $(25$ $\mathrm{ml}$; DE-52 cellulose, Whatman) equilibrated with $\mathrm{HGEDK}_{100}$ (i.e., $100 \mathrm{~mm} \mathrm{KCl}$ ). The column was washed with 5 volumes of $\mathrm{HGEDK}_{100}$, and bound protein was eluted at $400 \mathrm{mM} \mathrm{KCl}$. The $400 \mathrm{~mm} \mathrm{KCl}$ fraction was dialyzed to $100 \mathrm{~mm} \mathrm{KCl}$ and loaded onto a $15 \mathrm{ml}$ heparin-agarose column (Sigma). After washing with $\mathrm{HGEDK}_{100}$, the column was developed with two sequential elutions, one at $300 \mathrm{mM} \mathrm{KCl}$, and the second at $600 \mathrm{~mm}$ $\mathrm{KCl}$. The $300 \mathrm{mM} \mathrm{KCl}$ fraction containing $\mathrm{IEF}_{\mathrm{ga}}$ was dialyzed against $\mathrm{HGEDK}_{100}$, and chromatographed further on a $15-\mathrm{ml}$ salmon sperm DNA column (ssDNA), prepared as described previously (Graves et al. 1986). Washing of the column with HGEDK $_{100}$ was followed by elution at $300 \mathrm{~mm}$ and $800 \mathrm{~mm}$ $\mathrm{KCl}$. The $300 \mathrm{mM} \mathrm{KCl}$ pool, which contained $\mathrm{IEF}_{\mathrm{ga}}$, was subsequently subjected to sequence-specific DNA-affinity chromatography.

Sequence-specific DNA-affinity resin was prepared by the method of $\mathrm{Wu}$ et al. (1986). Complementary oligonucleotides $(200 \mu \mathrm{g} / \mathrm{g}$ resin) bearing the region of the ICP4 promoter containing the GA-rich repeats (see below) were annealed and coupled to CNBr-activated Sepharose 4B (Pharmacia).

5'-GCGGAACGGAAGCGGAAACGATCGCGGAACGGAAGCGGAAACCCCCC-3 3'-CGCCTTGCCTTCGCCTTTGCTAGCGCCTTGCCTTCGCCTTT - 5

Ten milliliters of the ssDNA Sepharose $0.3 \mathrm{M}$ fraction 10.2 $\mathrm{mg} / \mathrm{ml}$ protein) were diluted to $0.1 \mathrm{M} \mathrm{KCl}$, and added to $0.5 \mathrm{ml}$ of GA-Sepharose beads. Salmon sperm DNA $(5 \mu \mathrm{g})$ and poly[d(IC) $(10 \mu \mathrm{g})$ were added as competitor. The mixture was rocked at $4^{\circ} \mathrm{C}$, and subsequently loaded into a $10-\mathrm{ml}$ polypropylene column (BioRad). Flowthrough was collected, and the column then was developed by serial step elutions 13 column volumes each) at $0.1,0.3$, and $1 \mathrm{M} \mathrm{KCl}$. IEF $_{\mathrm{ga}}$ binding activity was present in the $0.3 \mathrm{M}$ fractions. To achieve additional purification, the above procedure was repeated twice more with the $0.3 \mathrm{M} \mathrm{KCl}$ pools.

Isolation and renaturation of polypeptides from SDSpolyacrylamide gels

Protein from the GA oligo-specific $0.3 \mathrm{M}$ fraction was concentrated by TCA precipitation and electrophoresed on a $10 \%$ SDS-polyacrylamide gel (Laemmli 1970). Protein bands were visualized by staining with Coomassie brilliant blue, excised from the gel, and electroeluted by the method of Hunkapillar et al. (1983). Bovine serum albumin $(20 \mu \mathrm{g})$ was added to each fraction, and protein was precipitated by the addition of 4 volumes of cold acetone. Precipitated protein was recovered by microcentrifugation and pellets were washed with $100 \%$ cold acetone. Renaturation was performed as described by Hager and Burgess (1980). Briefly, the protein pellets were resuspended in $50 \mu \mathrm{l}$ of $6 \mathrm{M}$ guanidine- $\mathrm{HCl}$ in $2 \times$ footprinting buffer $[50 \mathrm{~mm}$ Tris- $\mathrm{HCl}$ (pH 7.9), $6 \mathrm{~mm} \mathrm{MgCl}, 0.1 \mathrm{~mm}$ EDTA, $100 \mathrm{~mm} \mathrm{KCl}, 1$
mM DTT, $20 \%$ glycerol], and incubated at $22^{\circ} \mathrm{C}$ for $20 \mathrm{~min}$. An equal volume of $2 \times$ footprinting buffer (minus guanidine- $\mathrm{HCl}$ ) was then added, and samples were dialyzed at $4^{\circ} \mathrm{C}$ against 200 volumes of $2 \times$ footprinting buffer for $3 \mathrm{hr}$. Fifteen microliters of each sample were used in individual footprinting reactions. In the trial where 3 polypeptides were mixed, $5 \mu$ l of each were added to the reaction mixtures.

\section{Sequence-specific DNA affinity precipitation}

Strepavidin-biotin DNA affinity precipitation was performed as described (Franza et al. 1987; Sturm et al. 1987). Oligomers bearing the GA repeats were synthesized with complementary ends as shown below:

5'-GATCCGATCCGGCGGTTTCCGCTTCCGTTCCGC - 3'

3' - GCTAGGCCGCCAAAGGCGAAGGCAAGGCGCTAG-5'

The monomers were phosphorylated with unlabeled ATP, annealed, and ligated to yield catenates containing between 5 and 10 copies of the original repeat. The catenated GA probe was ${ }^{32}$ P-labeled by nick translation, and photobiotinylated. A biotinylated DNA fragment ( $\mathrm{rd} 9)$ from the SV40 promoter, generously provided by R. Sturm and W. Herr, was used as a control. Proteins bound to the strepavidin-agarose matrix were eluted by boiling in SDS sample buffer, separated on a 10\% SDS-polyacrylamide gel (Laemmli 1970), and visualized by silver staining (Wray et al. 1981).

\section{Acknowledgments}

We are grateful to R. Sturm and W. Herr for detailed instruction on the DNA precipitation assays, to R.-D. Kuhl and C. Weissmann for the provision of interferon constructs, and to C. Vinson for help with preparation of nuclear extracts. We also thank Bob Kingsbury for expert technical assistance, and our colleagues at the Carnegie Embryology Department for critical comments on the manuscript. K.L.L. is supported by a postdoctoral fellowship from the Leukemia Society of America, and S.L.M. is supported by the Howard Hughes Medical Institute at the Carnegie Institution of Washington.

\section{References}

Bohmann, D., T.J. Bos, A. Admon, T. Nishimura, P.K. Vogt, and R. Tjian. 1987. Human proto-oncogene c-iun encodes a DNA-binding protein with structural and functional properties of transcription factor AP1. Science 238: 1386-1392.

Bzik, D.J. and C.M. Preston. 1986. Analysis of DNA sequences which regulate the transcription of herpes simplex virus immediate early gene 3: DNA sequences required for enhancer-like activity and response to trans-activation by a virion polypeptide. Nucleic Acids Res. 14: 929-943.

Campbell, M.E.M., J.W. Palfreyman, and C.M. Preston. 1984. Identification of herpes simplex virus DNA sequences which encode a trans-acting polypeptide responsible for stimulation of immediate early transcription. J. Mol. Biol. 180: $1-19$.

Chodosh, L.A., A.S. Baldwin, R.W. Carthew, and P.A. Sharp. 1988. Human CCAAT-binding proteins have heterologous subunits. Cell 53: 11-24.

Cordingley, M.G., M.E.M. Campbell, and C.M. Preston. 1983. Functional analysis of a herpes simplex virus type 1 promoter: Identification of far-upstream regulatory sequences. Nucleic Acids Res. 11: 2347-2365. 
DeStasio, P.R. and M.W. Taylor. 1989. Trans-activation of herpes simplex virus type 1 immediate early genes is specifically inhibited by human recombinant interferon. Biochem. Biophys. Res. Commun. 159: 439-444.

Efstratiadis, A., F.C. Kafatos, and T. Maniatis. 1977. The primary structure of rabbit $\beta$-globin mRNA as determined from cloned DNA. Cell 10: 571-585.

Eisenberg, S.P., D.M. Coen, and S.L. McKnight. 1985. Promoter domains required for expression of plasmid-borne copies of the herpes simplex virus thymidine kinase gene in virus-infected mouse fibroblasts and microinjected frog oocytes. Mol. Cell. Biol. 5: 1940-1947.

Franza, B.R. Jr., S.F. Josephs, M.Z. Gilman, W. Ryan, and B. Clarkson. i987. Characterization of cellular proteins recognizing the HIV enhancer using a microscale DNA-affinity precipitation assay. Nature 330: 391-395.

Franza, B.R. Jr., F.J. Rauscher III, S.F. Josephs, and T. Curran. 1988. The fos complex and fos-related antigens recognize sequence elements that contain AP-1 binding sites. Science 239: $1150-1153$

Gaffney, D.F., I. McLauchlan, J.L. Whitton, and J.B. Clements. 1985. A modular system for the assay of transcription regulatory signals: The sequence TAATGARAT is required for herpes simplex virus immediate early gene activation. $\mathrm{Nu}$ cleic Acids Res. 13: 7847-7863.

Galas, D. and A. Schmitz. 1978. DNase footprinting: A simple method for the detection of protein-DNA binding specificity. Nucleic Acids Res. 5: 3157-3170.

Gerster, T. and R.G. Roeder. 1988. A herpes virus trans-activating protein interacts with transcription factor OTF-1 and other cellular proteins. Proc. Natl. Acad. Sci. 85: 63476351.

Goodbourn, S., H. Burstein, and T. Maniatis. 1986. The human $\beta$-interferon gene enhancer is under negative control. Cell 45: $601-610$.

Graves, B.J., P.F. Johnson, and S.L. McKnight. 1986. Homologous recognition of a promoter domain common to the MSV LTR and the HSV tk gene. Cell 44: 565-576.

Halazonetis, T.D., K. Georgopoulos, M.E. Greenberg, and P. Leder. 1988. c-JUN dimerizes with itself and with c-FOS, forming complexes of different DNA binding affinities. Cell 55: 917-924.

Hager, D.A. and R.R. Burgess. 1980. Elution of proteins from sodium dodecyl sulfate-polyacrylamide gels, removal of sodium dodecyl sulfate, and renaturation of enzymatic activity: Results with sigma subunit of Escherichia coli RNA polymerase, wheat germ DNA topoisomerase, and other enzymes. Anal. Biochem. 109: 76-86.

Honess, R.W. and B. Roizman. 1974. Regulation of herpesvirus macromolecular synthesis. I. Cascade regulation of the synthesis of three groups of viral proteins. J. Virol. 14: 8-19.

Hug, H., M. Costas, P. Staeheli, M. Aebi, and C. Weissmann. 1988. Organization of the murine $M x$ gene and characterization of its interferon- and virus-inducible promoter. Mol. Cell. Biol. 8: 3065-3079.

Hunkapillar, M.W., E. Lujan, F. Ostrander, and L.E. Hood. 1983. Isolation of microgram quantities of proteins from polyacrylamide gels for amino acid sequence analysis. Methods Enzymol. 91: 227-236.

Johnson, P.F., W.H. Landschulz, B.J. Graves, and S.L. McKnight. 1987. Identification of a rat liver nuclear protein that binds to the enhancer core element of three animal viruses. Genes Dev. 1: 133-146.

Johnson, P.F. and S.L. McKnight. 1989. Eukaryotic transcriptional regulatory proteins. Annu. Rev. Biochem. 58: 799839.
Jones, K.A. and R. Tiian. 1985. Sp1 binds to promoter sequences and activates herpes simplex virus 'immediate early' gene transcription in vitro. Nature 317: 179-182.

Keller, A.D. and T. Maniatis. 1988. Identification of an inducible factor that binds to a positive regulatory element of the human $\beta$-interferon gene. Proc. Natl. Acad. Sci. 85: 33093313.

Kristie, T.M. and B. Roizman. 1984. Separation of sequences defining basal expression from those conferring $\alpha$-gene recognition within the regulatory domains of herpes simplex virus $1 \alpha$-genes. Proc. Natl. Acad. Sci. 81: 4065-4069.

1987. Host cell proteins bind to the cis-acting site required for virion-mediated induction of herpes simplex virus 1 a-genes. Proc. Natl. Acad. Sci. 84: 71-75.

1988. Differentiation and DNA contact points of host proteins binding at the cis site for virion-mediated induction of $\alpha$-genes of herpes simplex virus 1. J. Virol. 62: 1145-1157.

Kuhl, F.-D., J. de la Fuente, M. Chaturvedi, S. Parimoo, J. Ryals, F. Meyer, and C. Weissmann. 1987. Reversible silencing of enhancers by sequences derived from the human IFN- $\alpha$ promoter. Cell 50: 1057-1069.

Laemmli, U.K. 1970. Cleavage of structural proteins during the assembly of the head of bacteriophage T4. Nature 227: 680685.

Lee, W., P. Mitchell, and R. Tiian. 1987. Purified transcription factor AP-1 interacts with TPA-inducible enhancer elements. Cell 49: 741-752.

Lindenmann, I. 1962. Resistance of mice to mouse-adapted influenza A virus. Virology 16: 203-204.

Lopata, M.A., D.W. Cleveland, and B. Sollner-Webb. 1984. High level transient expression of a chloramphenicol acetyl transferase gene by DEAE-dextran mediated DNA transfection coupled with a dimethyl sulfoxide or glycerol shock treatment. Nucleic Acids Res. 12: 5707-5717.

Mackem, S. and B. Roizman. 1982a. Differentiation between promoter and regulator regions of herpes simplex virus 1 : The functional domains and sequence of a movable $\alpha$ regulator. Proc. Natl. Acad. Sci. 79: 4917-4921.

1982b. Structural features of herpes simplex virus $\alpha$ gene 4,0 , and 27 promoter regulatory sequences which confer $\alpha$ regulation on chimeric thymidine kinase genes. I. Virol. 44: 939-949.

Marsden, H.S., M.E.M. Campbell, L. Haarr, M.C. Frame, D.S. Parris, M. Murphy, R.G. Hope, M.T. Muller, and C.M. Preston. 1987. The 65,000-Mr DNA-binding and viron trans-inducing proteins of herpes simplex virus type $1 . /$. Virol. 61: 2428-2437.

Maxam, A. and W. Gilbert. 1980. Sequencing end labeled DNA with base-specific chemical cleavages. Methods Enzymol. 65: 499-560.

McKnight, J.L.C., T.M. Kristie, and B. Roizman. 1987. Binding of the virion protein mediating $\alpha$ gene induction in herpes simplex virus l-infected cells to its cis site requires cellular proteins. Proc. Natl. Acad. Sci. 84: 7061-7065.

Mittnacht, S., P. Straub, H. Kirchner, and H. Jacobsen. 1988. Interferon treatment inhibits onset of herpes simplex virus immediate-early transcription. Virology 164: 201-210.

Nakabeppu, Y., K. Ryder, and D. Nathans. 1988. DNA binding activities of three murine JUN proteins: stimulation by FOS. Cell 57: 907-915.

O'Hare, P. and G.S. Hayward. 1987. Comparison of upstream sequence requirements for positive and negative regulation of a herpes simplex virus immediate-early gene by three virus-encoded trans-acting factors. I. Virol. 61: 190-199.

O'Hare, P. and C.R. Goding. 1988. Herpes simplex virus regulatory elements and the immunoglobulin octamer domain 
bind a common factor and both are targets for virion transactivation. Cell 52: 435-445.

Preston, C.M., M.C. Frame, and M.E.M. Campbell. 1988. A complex formed between cell components and a herpes simplex virus structural polypeptide binds to a viral immediate early gene regulatory DNA sequence. Cell 52: 425-434.

Post, L.E., S. Mackem, and B. Roizman. 1981. Regulation of $\alpha$ genes of herpes simplex virus: Expression of chimeric genes produced by fusion of thymidine kinase with $\alpha$ gene promoters. Cell 24: 555-565.

Ptashne, M. 1988. How eukaryotic transcriptional activators work. Nature 335: 683-689.

Rauscher, F.J. III, D.R. Cohen, T. Curran, T.J. Bos, P.K. Vogt, D. Bohmann, R. Tjian, and B.R. Franza, Jr. 1988a. FOS-associated protein $\mathrm{p} 39$ is the product of the iun proto-oncogene. Science 240: 1010-1016.

Rauscher, F.J. III, L.C. Sambucetti, T. Curran, R.J. Distel, and B.M. Spiegelman. 1988b. Common DNA binding site for FOS protein complexes and transcription factor AP-1. Cell 52: $471-480$.

Rauscher, F.J. III, P.J. Voulalas, B.R. Franza Jr., and T. Curran. 1988c. FOS and JUN bind cooperatively to the AP-1 site: Reconstitution in vitro. Genes Dev. 2: 1687-1699.

Revel, M. and J. Chebath. 1986. Interferon-activated genes. Trends Biochem. Sci. 11: 166-170.

Ryals, J., P. Dierks, H. Ragg, and C. Weissmann. 1985. A 46-nucleotide promoter segment from an IFN- $\alpha$ gene renders an unrelated promoter inducible by virus. Cell 41: 497-507.

Sadowski, I., J. Ma, S. Triezenberg, and M. Ptashne. 1988. GAL4-VP16 is an unusually potent transcriptional activator. Nature 335: 563-564.

Staeheli, P., O. Haller, W. Boll, J. Lindenmann, and C. Weissmann. 1986. Mx protein: Constitutive expression in 3T3 cells transformed with cloned Mx cDNA confers selective resistance to influenza virus. Cell 44: 147-158.

Sturm, R., T. Baumruker, B.R. Franza, Jr., and W. Herr. 1987. A $100-\mathrm{kD}$ HeLa cell octamer binding protein (OBP100) interacts differently with two separate octamer-related sequences within the SV40 enhancer. Genes Dev. 1: 11471160.

Triezenberg, S.J., K.L. LaMarco, and S.L. McKnight. 1988a. Evidence of DNA : protein interactions that mediate HSV-l immediate early gene activation by VP16. Genes Dev. 2: 730742.

Triezenberg, S.J., R.C. Kingsbury, and S.L. McKnight. 1988b. Functional dissection of VP16, the trans-activator of herpes simplex virus immediate early gene expression. Genes Dev. 2: $718-729$.

Wray, W., T. Boulikas, V.P. Wray, and R. Hancock. 1981. Silver staining of proteins in polyacrylamide gels. Anal. Biochem. 118: 197-203.

Wu, C., S. Wilson, B. Walker, I. Dawid, T. Paisley, V. Zimarino, and $\mathrm{H}$. Ueda. 1987. Purification and properties of Drosophila heat shock activator protein. Science 238: 1247-1253. 


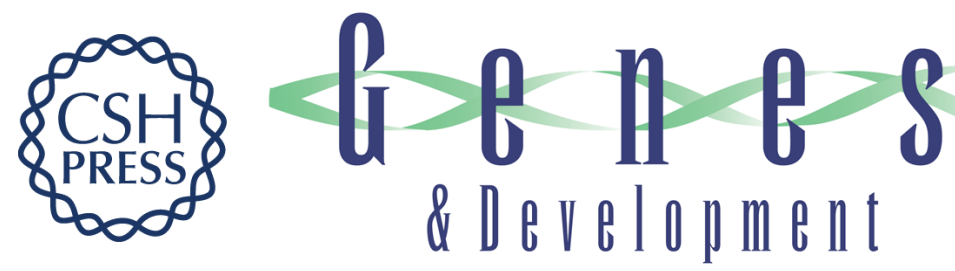

\section{Purification of a set of cellular polypeptides that bind to the purine-rich cis-regulatory element of herpes simplex virus immediate early genes.}

K L LaMarco and S L McKnight

Genes Dev. 1989, 3:

Access the most recent version at doi:10.1101/gad.3.9.1372

References This article cites 56 articles, 22 of which can be accessed free at: http://genesdev.cshlp.org/content/3/9/1372.full.html\#ref-list-1

License

Email Alerting Receive free email alerts when new articles cite this article - sign up in the box at the top Service right corner of the article or click here.

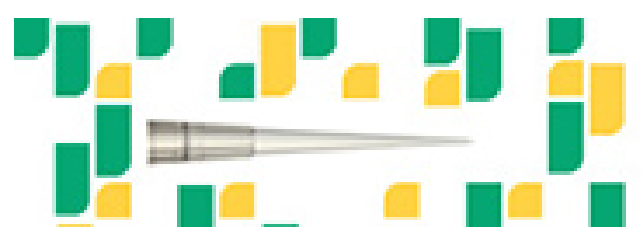

Focused on your science. 